\title{
Henry Reaction between Benzaldehyde and Nitromethane over Solid Base Catalysts: A Green Protocol
}

\author{
Magda H. Abdellattif ${ }^{*}$, Hany Mahmoud Mohamed ${ }^{2}$ \\ ${ }^{1}$ Pharmaceutical chemistry department, Deanship of Scientific research Taif University, Taif, KSA \\ ${ }^{2}$ Chemistry Department, Faculty of Science, Taif University, Taif, KSA \\ Email: *magdah11uk@hotmail.com,m.hasan@tu.edu.sa
}

How to cite this paper: Abdellattif, M.H. and Mohamed, H.M. (2018) Henry Reaction between Benzaldehyde and Nitromethane over Solid Base Catalysts: A Green Protocol. Green and Sustainable Chemistry, 8, 139-155.

https://doi.org/10.4236/gsc.2018.82010

Received: February 18, 2018

Accepted: April 27, 2018

Published: April 30, 2018

Copyright $\odot 2018$ by authors and Scientific Research Publishing Inc. This work is licensed under the Creative Commons Attribution International License (CC BY 4.0).

http://creativecommons.org/licenses/by/4.0/

\begin{abstract}
The development of environmentally benign solid base catalysts instead of the soluble bases for $\mathrm{C}-\mathrm{C}$ bond formation in organic reactions especially Henry reactions with nitroalkanes compounds is of intense research activity in the bulk and fine chemical chemistry in order to achieve the selectivity of the desired product and the reduction of the salts formed due to soluble bases neutralization. While using of LDHs catalysts in the synthesis of nitro alcohols is of great interest because LDHs (double layered hydroxides) is of unique properties and an excellent catalytic property. The nitroalcohols are obtained in a very good yield while using catalyst either by conventional at $90^{\circ} \mathrm{C}$ in liquid phase, microwave or sonoenergy without solvent methods, and the results yields are compared. A series of different nitro alcohols from $(\mathrm{a}-\mathrm{o})$ were prepared, the catalytic test reaction were carried out using benzaldehyde and their derivatives with nitromethane and their derivatives. A series of LDHs catalysts were prepared also and studying of the catalytic effect on the reactions was carried out. Properties of the compounds prepared were characterized by IR, MNR, and GC-MS.
\end{abstract}

\section{Keywords \\ C-C Bond Formation, Henry Reaction, Base Catalyst}

\section{Introduction}

The fine chemical industry has experienced remarkable interest over the past few years due to the high requirements for products like pharmaceuticals, pesticides, fragrances, flavorings and food additives [1]. 
The classical methods for the $\mathrm{C}-\mathrm{C}$ coupling in Henry reaction using soluble bases such as alkali metal hydroxides, carbonates, bicarbonates, alkoxides, alkaline earth metal hydroxide, and aluminium ethoxides, complexes, and also organic bases such as primary, secondary and tertiary amines usually resulted in dehydrated products [2]. Therefore, careful control of the basic properties of the reaction medium is vital to obtain better yields of $\beta$-nitroalcohols. However, the efforts done by the researchers in the literature required longer reaction times and produced moderate yields [3] [4]. The stoichiometric organic synthesis largely applied so far resulted in large quantities of inorganic salts as byproducts; the disposal of such material causes a serious problem due to the important environmental issues [5].

The remarkable progress in the competition in the industry has pushed the researchers to develop more effective catalytic processes in the synthesis of fine chemicals.

The products of the Henry reaction, representing C-C bond formation, are important materials extensively used in many organic syntheses [6]. The greatest challenge in the selective synthesis of 2-nitroalkanols in the multiple product options such as aldol olefin and its polymer and Cannizaro products is the selection of the right type of base [7].

Significant improvements to the Henry reaction have been achieved by using silyl nitronates in the presence of fluoride ion or altematively $\alpha$ - $\alpha$ doubly deprotonated primary nitroalkanes [8].

Both of these procedures have proved to be useful for the stereo selective preparation of vicinal amino alcohols under drastic conditions, which reduced diastereoselectivity with aromatic aldehydes. In order to obtain better yields and diastereoselectivity of 2-nitroalcohols, it is necessary to develop new procedures employing heterogeneous catalysts with basic character [9].

The homogenous catalytic methodologies reported in the literature have many disadvantages, such as disposal of waste and difficulty to recover the catalyst from the products. In the last decade, there were notable improvements in the development of heterogeneous catalyst for Henry reaction [10].

Heterogeneous catalysis induced by solid catalysts such as basic alumina [11], alumina-KF [12] and homogeneous phase transfer catalysis with surfactants [13] in bi-phase system, the two divergent approaches being explored are aimed at achieving higher atom selectivity. The solid base catalysts provide an alternative to the classical soluble bases with emphasize to avoid the environmental problems caused by salt formation and hazardous conditions [14]. Previous wok in the synthesis of fine chemicals using layered double hydroxides revealed the importance of such materials and discovered its environmentally favorable routes in comparison to the other catalysts [15]-[20].

\section{Results and Discussion}

Henry reaction is a base-catalyzed $\mathrm{C}-\mathrm{C}$ bond-forming reaction between nitroal- 
kanes and aldehydes or ketones. It is similar to the Aldol Addition, and also referred to as the Nitro Aldol Reaction.

If acidic protons are available $(\mathrm{H})$, the products tend to eliminate water to give nitroalkenes. Therefore, only small amounts of base should be used if the isolation of the $\beta$-hydroxy nitro-compounds is desired, Scheme 1.

To generalize this reaction methodology three experiments were carried out using different LDHs catalysts which may also be called hydrotalcite, and their thermally activated form (calcined) were very active and very useful in many different organic synthesis reactions. Henry reaction was carried out under three conditions by these catalysts, by conventional method, and microwave method [21].

$\mathrm{Cu}$ LDHs series was used in this research which were: uncalcined HT-Solgel Cu:Mg:Al (1:2:1), calcined Cu:Mg:Al (1:2:1), clacined Cu:Mg:Al (2:1:1) and finally calcines $\mathrm{Cu}: \mathrm{Al}(3: 1)$. Table 1 represents the nitroalkanes and the aldehydes used.

To compare the three types of this condensation reaction yield, it should be taken in consideration from literature the most optimum temperature for this reaction by conventional method was $90^{\circ} \mathrm{C}$. While in this research temperature in conventional method decreased by using catalysts, Table 1 represented the yield of this nitro aldol condensation reaction using three methods.

The use of uncalcined HT was not efficient enough like the other catalyst used and the reaction yields and time were near to the reaction yield and time in the absence of any catalyst and solvents in spite of temperature change and decreased to $60^{\circ} \mathrm{C}$, as shown in Table 4 . Using of different calcined catalysts at fixed weight $0.5 \mathrm{~g}$, temperature $50^{\circ} \mathrm{C}$ for conventional method, fixed microwave temperature many different results but in a good and acceptable yield \% for all of the catalysts used as illustrated in Tables 5-7. These good results directed us to make a comparison between the catalysts themselves and their activities toward the nitroaldol reaction.

The higher activity of LDHs catalysts were observed because of their structure flexibility as a host compound during the formation of final nirtoalcohol. It was observed also at fixed amount of catalyst used, fixed temperature, and fixed M.W conditions, changing of the catalyst type led to decrease in time of the reaction required to be finished and increase of the reaction yield.

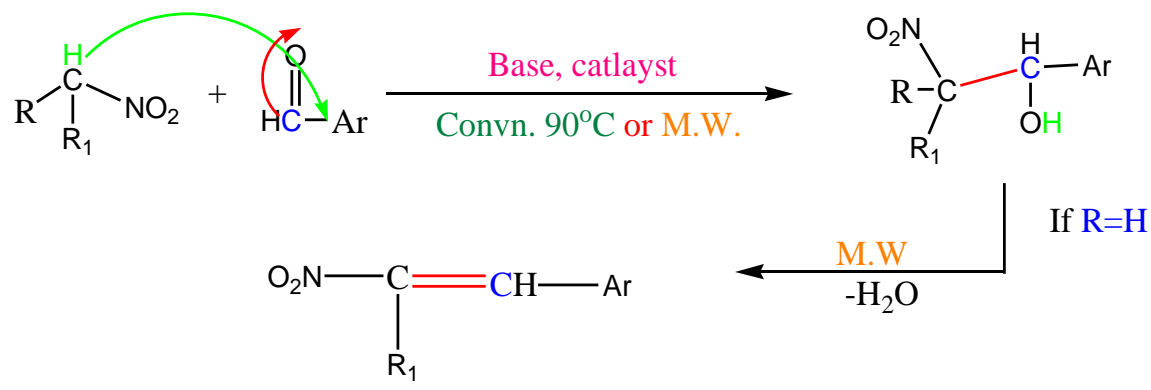

Scheme 1. Henry reaction and its mechanism. 
Table 1. Compounds Structures.

\begin{tabular}{|c|c|c|c|}
\hline Compound & $\mathbf{R}$ & R1 & $\mathrm{Ar}$ \\
\hline A & $\mathrm{H}$ & $\mathrm{H}$ & 4-cholorobenzaldehyde \\
\hline B & $\mathrm{CH}_{3}$ & $\mathrm{H}$ & 4-cholorobenzaldehyde \\
\hline c & $\mathrm{CH}_{3}$ & $\mathrm{CH}_{3}$ & 4-cholorobenzaldehyde \\
\hline $\mathrm{D}$ & $\mathrm{H}$ & $\mathrm{H}$ & 3, 5 Dibromo benzaldehyde \\
\hline $\mathbf{E}$ & $\mathrm{CH}_{3}$ & $\mathrm{H}$ & 3, 5 Dibromo benzaldehyde \\
\hline $\mathbf{F}$ & $\mathrm{CH}_{3}$ & $\mathrm{CH}_{3}$ & 3, 5 Dibromo benzaldehyde \\
\hline G & $\mathrm{H}$ & $\mathrm{H}$ & 5-Bromo-3-nitro, Salicylaldehyde \\
\hline $\mathrm{H}$ & $\mathrm{CH}_{3}$ & $\mathrm{H}$ & 5-Bromo-3-nitro, Salicylaldehyde \\
\hline I & $\mathrm{CH}_{3}$ & $\mathrm{CH}_{3}$ & 5-Bromo-3-nitro, Salicylaldehyde \\
\hline $\mathrm{J}$ & $\mathrm{H}$ & $\mathrm{H}$ & 2-Nitro-benzaldehyde \\
\hline K & $\mathrm{CH}_{3}$ & $\mathrm{H}$ & 2-Nitro-benzaldehyde \\
\hline $\mathbf{L}$ & $\mathrm{CH}_{3}$ & $\mathrm{CH}_{3}$ & 2-Nitro-benzaldehyde \\
\hline $\mathbf{M}$ & $\mathrm{H}$ & $\mathrm{H}$ & 4-methoxy benzaldehyde \\
\hline $\mathrm{N}$ & $\mathrm{CH}_{3}$ & $\mathrm{H}$ & 4-methoxy benzaldehyde \\
\hline $\mathrm{O}$ & $\mathrm{CH}_{3}$ & $\mathrm{CH}_{3}$ & 4-methoxy benzaldehyde \\
\hline
\end{tabular}

Table 2. Comparison between different methods time and yield without any catalysts.

\begin{tabular}{|c|c|c|c|c|}
\hline \multirow[b]{2}{*}{ Compound } & \multicolumn{2}{|c|}{ Conventional at $90^{\circ} \mathrm{C}$} & \multicolumn{2}{|c|}{ Microwave } \\
\hline & $\begin{array}{l}\text { Time } \\
\text { Min. }\end{array}$ & Yield \% & $\begin{array}{l}\text { Time } \\
\text { Min. }\end{array}$ & Yield \% \\
\hline a & 480 & 62 & 6.5 & 80 \\
\hline b & 360 & 66 & 6.5 & 82 \\
\hline c & 480 & 65 & 5.5 & 86 \\
\hline $\mathrm{d}$ & 420 & 61 & 6 & 80 \\
\hline e & 360 & 59 & 4.5 & 84 \\
\hline $\mathrm{f}$ & 360 & 67 & 4.5 & 83 \\
\hline g & 360 & 66 & 5.5 & 83 \\
\hline $\mathrm{h}$ & 300 & 58 & 5.5 & 87 \\
\hline $\mathbf{i}$ & 420 & 63 & 5 & 87 \\
\hline j & 360 & 70 & 4.5 & 81 \\
\hline $\mathbf{k}$ & 420 & 64 & 5 & 81 \\
\hline 1 & 360 & 61 & 4.5 & 82 \\
\hline m & 360 & 66 & 4 & 84 \\
\hline $\mathbf{n}$ & 360 & 66 & 6 & 82 \\
\hline o & 480 & 66 & 4.5 & 83 \\
\hline
\end{tabular}


Table 3. Comparison between different methods time and yield using uncalcined HT-Solgel (0.5 g).

\begin{tabular}{ccccc}
\hline \multirow{2}{*}{ Compound } & \multicolumn{2}{c}{ Conventional $60^{\circ} \mathrm{C}$} & \multicolumn{2}{c}{ Microwave } \\
\cline { 2 - 5 } & Time min. & Yield \% & Time Min. & Yield \% \\
\hline a & 300 & 61 & 4.5 & 90 \\
b & 360 & 64 & 4.5 & 88 \\
c & 360 & 48 & 3.5 & 88 \\
d & 270 & 60 & 4 & 92 \\
e & 300 & 58 & 4.5 & 90 \\
f & 360 & 56 & 3.5 & 88 \\
g & 360 & 63 & 3.5 & 84 \\
h & 300 & 59 & 3.5 & 90 \\
i & 240 & 65 & 3.5 & 90 \\
j & 270 & 70 & 3.3 & 80 \\
k & 300 & 64 & 3 & 83 \\
1 & 300 & 69 & 4 & 93 \\
m & 300 & 71 & 3 & 94 \\
n & 300 & 68 & 4 & 90 \\
o & 300 & & 3 & 92 \\
\hline & & 72 & & 90 \\
\hline
\end{tabular}

Table 4. Comparison between different methods time and yield using Cu:Mg:Al (1:2:1) (0.5 g).

\begin{tabular}{|c|c|c|c|c|}
\hline \multirow{2}{*}{ Compound } & \multicolumn{2}{|c|}{ Conventional $60^{\circ} \mathrm{C}$} & \multicolumn{2}{|c|}{ Microwave } \\
\hline & Time min. & Yield \% & Time min. & Yield \% \\
\hline a & 270 & 70 & 3.5 & 95 \\
\hline b & 270 & 73 & 3.5 & 94 \\
\hline c & 240 & 72 & 3.5 & 92 \\
\hline $\mathrm{d}$ & 240 & 75 & 3 & 94 \\
\hline e & 240 & 79 & 3.5 & 93 \\
\hline $\mathrm{f}$ & 180 & 77 & 2.5 & 93 \\
\hline g & 210 & 76 & 2.8 & 94 \\
\hline $\mathrm{h}$ & 210 & 68 & 3.5 & 93 \\
\hline $\mathbf{i}$ & 210 & 69 & 3 & 92 \\
\hline$j$ & 240 & 76 & 2.6 & 91 \\
\hline $\mathbf{k}$ & 270 & 75 & 3 & 91 \\
\hline 1 & 240 & 78 & 3 & 89 \\
\hline $\mathrm{m}$ & 240 & 76 & 2.4 & 94 \\
\hline $\mathbf{n}$ & 210 & 78 & 3 & 93 \\
\hline o & 210 & 76 & 2.6 & 94 \\
\hline
\end{tabular}


Table 5. Comparison between different methods time and yield using calcined $\mathrm{Cu}: \mathrm{Mg}: \mathrm{Al}$ $(1: 2: 1)(0.5 \mathrm{~g})$.

\begin{tabular}{ccccc}
\hline \multirow{2}{*}{ Compound } & \multicolumn{2}{c}{ Conventional $60^{\circ} \mathrm{C}$} & \multicolumn{2}{c}{ Microwave } \\
\cline { 2 - 5 } a & Time min. & Yield \% & Time min. & Yield \% \\
\hline b & 180 & 70 & 3 & 95 \\
c & 180 & 73 & 3.5 & 95 \\
d & 210 & 72 & 3.5 & 96 \\
e & 210 & 75 & 2.6 & 94 \\
f & 210 & 79 & 2.5 & 93 \\
g & 210 & 77 & 2.5 & 96 \\
h & 180 & 76 & 2.5 & 96 \\
i & 220 & 68 & 2.5 & 95 \\
j & 230 & 69 & 2.5 & 94 \\
k & 230 & 76 & 2.3 & 95 \\
1 & 280 & 75 & 3 & 94 \\
$\mathbf{m}$ & 180 & 78 & 2.5 & 95 \\
$\mathbf{n}$ & 250 & 76 & 2 & 94 \\
$\mathbf{0}$ & 200 & 78 & 2.5 & 96 \\
\hline
\end{tabular}

Table 6. Comparison between different methods time and yield using clacined $\mathrm{Cu}: \mathrm{Mg}: \mathrm{Al}$ $(2: 1: 1)(0.5 \mathrm{~g})$.

\begin{tabular}{|c|c|c|c|c|}
\hline \multirow{2}{*}{ Compound } & \multicolumn{2}{|c|}{ Conventional $60^{\circ} \mathrm{C}$} & \multicolumn{2}{|c|}{ Microwave } \\
\hline & Time min. & Yield \% & Time min. & Yield \% \\
\hline a & 65 & 82 & 2.8 & 95 \\
\hline b & 60 & 83 & 2 & 95 \\
\hline c & 60 & 84 & 2.5 & 96.5 \\
\hline$d$ & 55 & 83 & 2.5 & 95 \\
\hline e & 55 & 83 & 2 & 94.5 \\
\hline $\mathrm{f}$ & 55 & 85 & 2 & 96 \\
\hline g & 58 & 86 & 2.2 & 98 \\
\hline $\mathrm{h}$ & 60 & 85 & 2 & 97.5 \\
\hline i & 60 & 85 & 2.5 & 97 \\
\hline $\mathbf{j}$ & 62 & 88 & 2 & 96 \\
\hline k & 66 & 84 & 2 & 95 \\
\hline 1 & 65 & 86 & 2 & 96 \\
\hline $\mathbf{m}$ & 65 & 85 & 2 & 96 \\
\hline $\mathbf{n}$ & 63 & 90 & 2 & 94.5 \\
\hline o & 63 & 92 & 2 & 96.5 \\
\hline
\end{tabular}


Table 7. Comparison between different methods time and yield using clacined $\mathrm{Cu}: \mathrm{Al}$ $(3: 1)(0.5 \mathrm{~g})$.

\begin{tabular}{ccccc}
\hline \multirow{2}{*}{ Compound } & \multicolumn{2}{c}{ Conventional $60^{\circ} \mathrm{C}$} & \multicolumn{2}{c}{ Microwave } \\
\cline { 2 - 5 } a & Time min. & Yield \% & Time min. & Yield \% \\
\hline b & 55 & 92 & 2.2 & 98.9 \\
c & 55 & 91 & 2 & 99 \\
d & 58 & 92 & 2.2 & 98.5 \\
e & 50 & 93.5 & 1.8 & 99 \\
$\mathbf{f}$ & 48 & 92.6 & 1.5 & 98.5 \\
$\mathbf{g}$ & 48 & 94.8 & 1.5 & 98.3 \\
$\mathbf{h}$ & 46 & 92 & 1.5 & 97.8 \\
$\mathbf{i}$ & 46 & 91 & 1.5 & 97.5 \\
$\mathbf{j}$ & 50 & 88 & 1.5 & 98 \\
$\mathbf{k}$ & 54 & 89 & 1.3 & 99 \\
$\mathbf{1}$ & 45 & 91 & 1.5 & 99 \\
$\mathbf{m}$ & 50 & 89 & 1.3 & 99 \\
$\mathbf{n}$ & 45 & 98.8 & 1.1 & 99 \\
$\mathbf{0}$ & 40 & 93 & 1 & 98.6 \\
\hline
\end{tabular}

For Cu:Al 3:1 and Cu:Mg:Al 2:1:1 the reaction tended to be completed in a short time. This can be explained by the catalyst which has higher copper content was more active in this serious. One also could observe that aldehyde which has little electron withdrawing group influence and enhance the reaction activity. By the way microwave yields are the highest every time.

By the way from Table 3 the reaction tented to be finished between $4-6.5$ min using M.W and 300 - 480 min using conventional method by maximum yield $87 \%$ and $63 \%$ respectively. While using solvated catalyst reaction Table 2 completed at $3-4 \mathrm{~min} \mathrm{M} . \mathrm{W}$ and $300 \mathrm{~min}$. by using conventional method in a max. Yield \% 94\% and 71\% respectively. The 99\% yield percentage obtained by using clacined Cu:Al 3:1, using M.W at 1.5 - 2 min. But using of calcined $\mathrm{Cu}: \mathrm{Mg}: \mathrm{Al}$ (2:1:1) gave 98\% yield as a highest yield percentage this may attributed to the crystalline structure of $\mathrm{Cu}: \mathrm{Al} 3: 1$ [22]. The difference in reaction catalysts, yield and time was illustrated in Figures 1-5.

Where:

Figure 1: Compare between different methods time and yield without any catalysts.

Figure 2: Compare the yield \% change during use of different catalysts, by MW irradiation method.

Figure 3: Compare the time change during use of different catalysts, MW irradiation method. 
Figure 4: Compare time change during use of different catalysts, by conventional method.

Figure 5: Compare the yield \% change during use of different catalysts, conventional method.

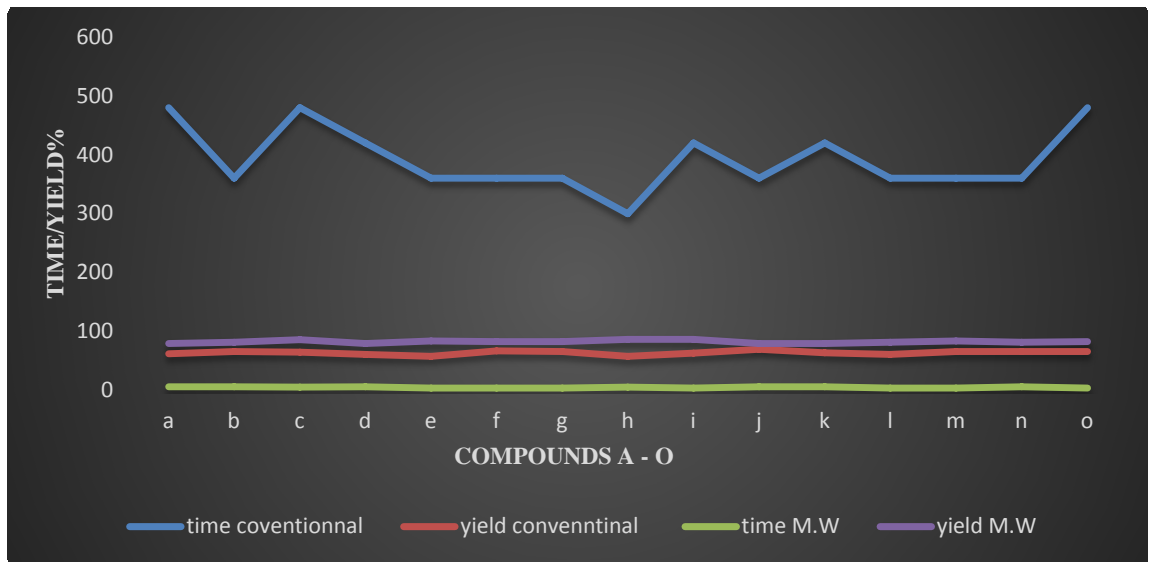

Figure 1. Comparison between different methods time and yield without any catalysts.

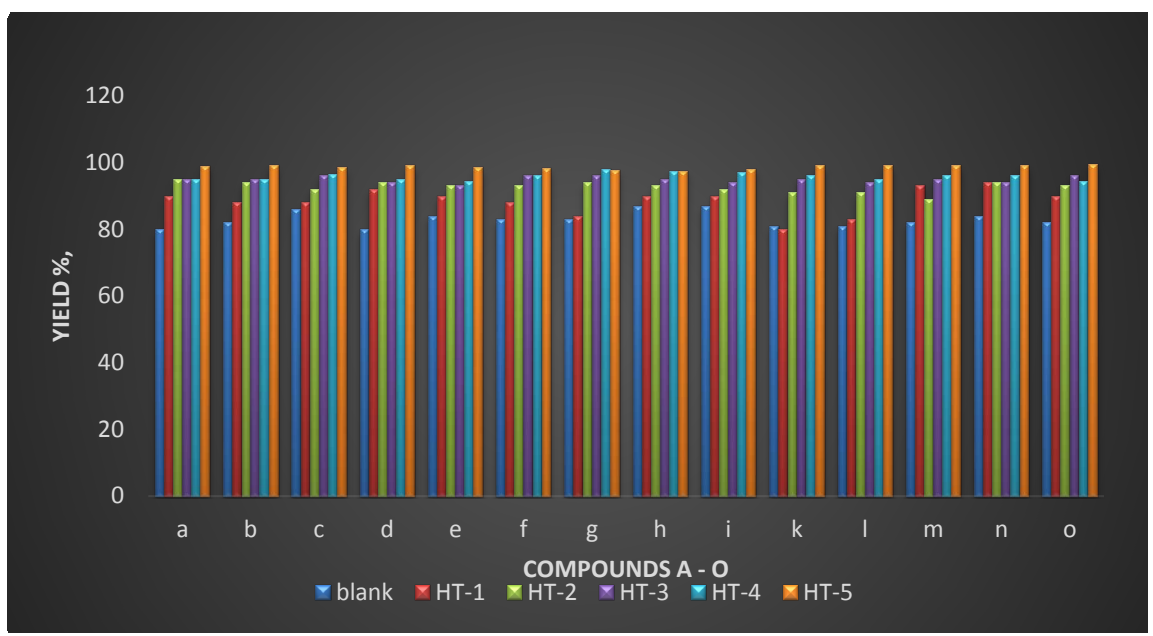

Figure 2. \% Yield change during use of different catalysts, MW.

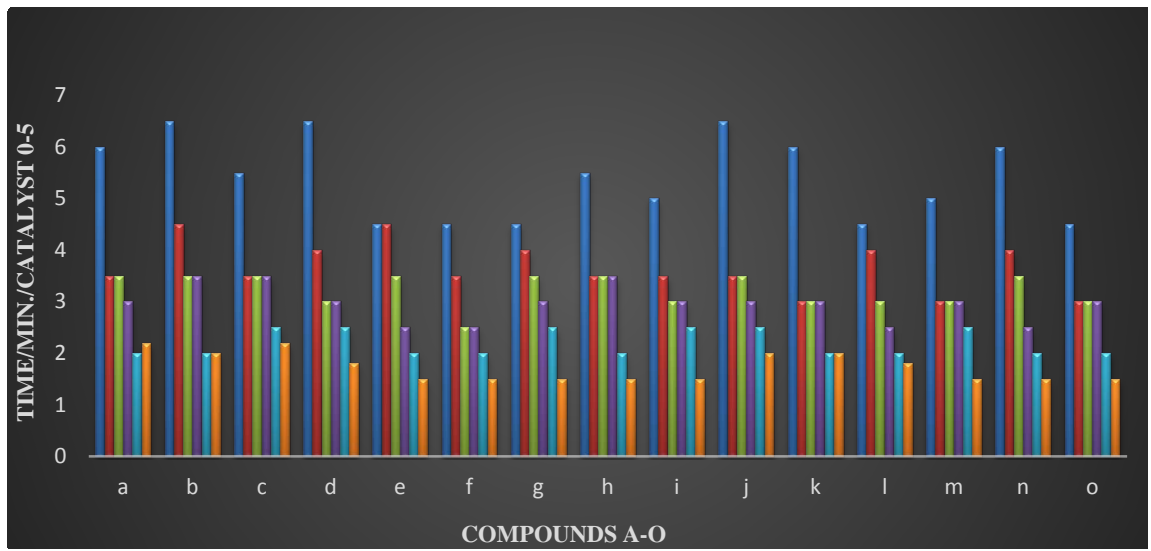

Figure 3. Time change during use of different catalysts, MW. 


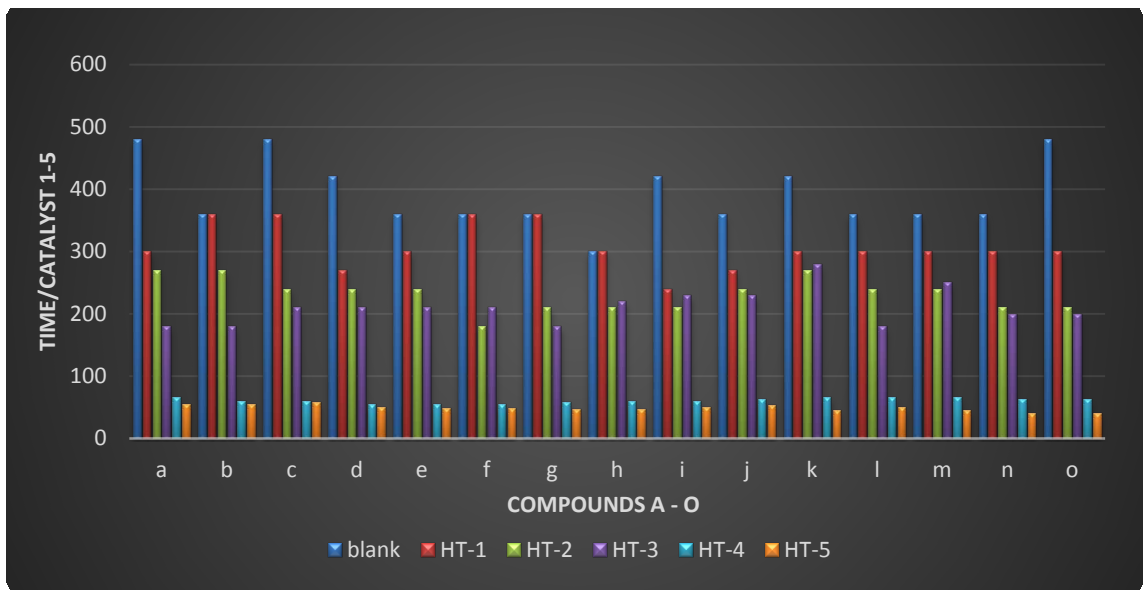

Figure 4. Time change during use of different catalysts, conventional.

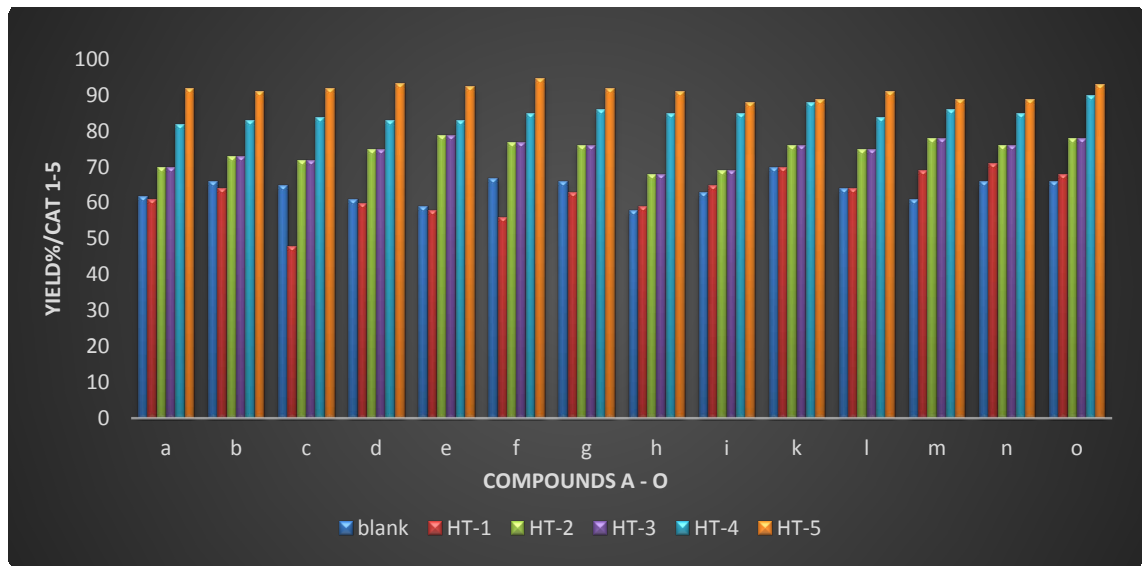

Figure 5. \% Yield change during use of different catalysts, conventional.

$\mathrm{XRD}$ of the catalysts were represented in Figure 6, indicating the diffraction patterns of HT-1, HT-2, HT3, HT-4 and HT-5, which gave information about the crystalline nature of these five catalysts. Catalyst showed diffraction pattern at $2 \theta$ $35.6^{\circ}, 38.8^{\circ}, 48.8^{\circ}, 53.6^{\circ}, 58.5^{\circ}, 61.5^{\circ}, 66.3^{\circ}, 68.1^{\circ}$ and $75.4^{\circ}$. The catalyst was also analyzed after reuse by XRD and it showed no significant change. XRD patterns catalysts layered structure was obtained (Ref. Pattern 22-0700, JCPDS) [23].

FTIR (Fourier transform infrared spectroscopy) of HT catalyst series sample (Figure 7) showed a broad band at nearly $3500 \mathrm{~cm}^{-1}$ belonged to stretching vibration $\mathrm{OH}$. This might be because of the water interlayer and hydroxyl groups in HT series [24]. Small weak band appeared at 1650-1700. This might be related to the bridging mode $\mathrm{H}_{2} \mathrm{O}-\mathrm{CO}_{3}^{2-}$. Because of the vibrational mode of water a weak peak at $1590 \mathrm{~cm}^{-1}$ appeared in the infrared spectrum which might be related to interlayer of water [25]. The peak around $1340 \mathrm{~cm}^{-1}$ belonged to carbonate. All of carbonate bands of HT catalysts were removed completely during calcinations at $450^{\circ} \mathrm{C}$ [26]. This was as a result of complete thermal decomposition of hydrated catalysts phase into mixed metal oxides, which gave a good indication of the XRD data [27] [28]. 


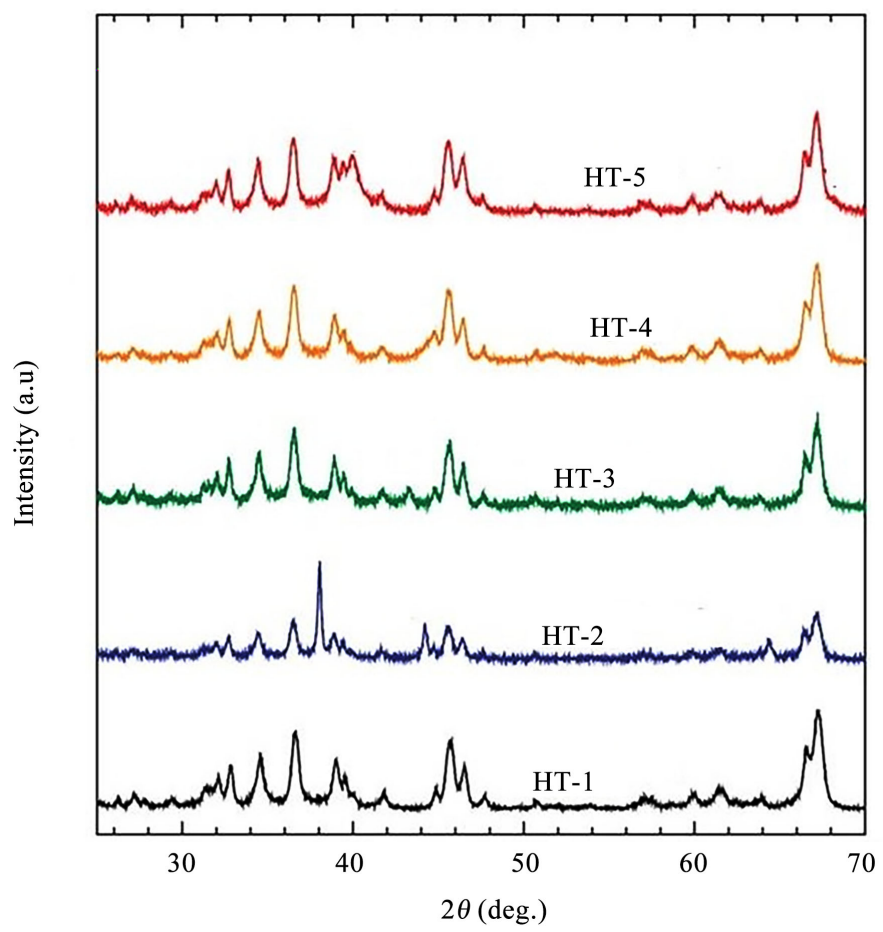

Figure 6. XRD for HT catalysts series.

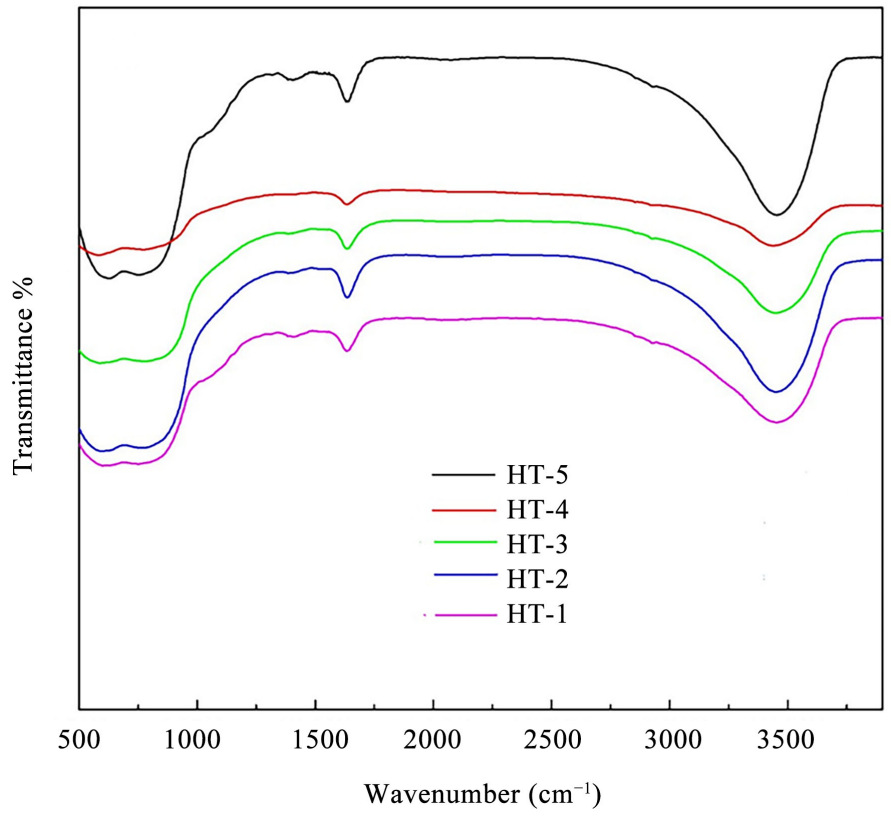

Figure 7. FTIR of HT-catalyst series.

\section{Methodology}

All chemicals used were purchased from Sigma Alderich, analytical trade. ${ }^{1} \mathrm{H}-\mathrm{NMR}$ spectra, ${ }^{13} \mathrm{C}-\mathrm{NMR}$ spectra were recorded on Bruker AM250 NMR spectrometer using $\mathrm{CDCl}_{3}$ as solvent for the samples. Mass spectra were recorded on Shimadzu LCMS-QP 800 LC-MS, IR for the synthesised compounds 
were recorded in potassium bromide discs on Shimadzu FT IR 8101 PC infrared spectrophotometer. Elemental analysis was obtained using PerkinElmer 2400 II series CHN Analyser. Thin-layer chromatography (TLC) was carried out on pre-coated Merck silica gel F254 plates to $80^{\circ}$. Melting points of the prepared compounds were measured on a Gallenkamp melting point apparatus.

1) Catalysts

a) Synthesis

Catalysts were prepared by co-precipitation methods as literature [29] [30], LDHs have the structures $\left[\mathrm{M}_{1-\mathrm{x}}^{2+}, \mathrm{M}_{\mathrm{x}}^{3+}(\mathrm{OH})_{2}\right]^{\mathrm{x}+}\left[\mathrm{A}_{\mathrm{x} / \mathrm{y}}\right]^{\mathrm{y}-} \cdot \mathrm{mH}_{2} \mathrm{O}$, where the divalent may be $\left(\mathrm{Mg}^{2+}, \mathrm{Cu}^{2+}, \mathrm{Fe}^{2+}, \mathrm{Co}^{2+}, \mathrm{Ni}^{2+}\right.$, or $\left.\mathrm{Zn}^{2+}\right)$, and the trivalent are metal cation (e.g., $\mathrm{Al}^{3+}, \mathrm{Cr}^{3+}, \mathrm{Ga}^{3+}, \mathrm{Ln}^{3+}, \mathrm{Mn}^{3+}$ or $\mathrm{Fe}^{3+}$ ) which forms the positively charged layers, where $\mathrm{A}^{\mathrm{y}-}$ are called inorganic or organic anions (e.g., $\mathrm{CO}_{3}^{2-}$, $\left.\mathrm{Cl}^{-}, \mathrm{SO}_{4}^{2-}, \mathrm{RCO}_{2}^{-}\right)$.

\section{i- HT-1 (LDH-As)}

Mixing of magnesium nitrate $\mathrm{Mg}\left(\mathrm{NO}_{3}\right)_{2} \cdot 6 \mathrm{H}_{2} \mathrm{O} 0.2213 \mathrm{~mol}$, and aluminium nitrate $\mathrm{Al}\left(\mathrm{NO}_{3}\right)_{3} 0.0885 \mathrm{~mol}$, in a $0.2213 \mathrm{~L}$ of dist. $\mathrm{H}_{2} \mathrm{O}$, mix (A). Mixing of $0.7162 \mathrm{~mol}$ of $\mathrm{NaOH}$, and $0.2084 \mathrm{~mol}$ of $\mathrm{Na}_{2} \mathrm{CO}_{3}$, in a $0.221 \mathrm{~L}$, mix (B). Drop using a burette drops from Mix (A) and Mix (B) to a Round bottom flask $1 \mathrm{~L}$ containing $0.5 \mathrm{~L}$ distilled water under vigorous stirring and heating at $60^{\circ} \mathrm{C}$ and measure $\mathrm{pH}$ during precipitation to be $10-11$. Keep the temperature at $60^{\circ} \mathrm{C}$ overnight $(16 \mathrm{~h})$ in water bath. Filter using (Whatmann 1 filter paper) and washing the cake by hot distilled water till $\mathrm{pH}=7$. Dry the filtrate at $80^{\circ} \mathrm{C}$ in an oven for $16 \mathrm{~h}$.

\section{ii- Cu:Mg:Al (1:2:1) HT-2, Clacined Cu:Mg:Al (1:2:1) HT-3, and Clacined Cu:Mg:Al (2:1:1) HT-4}

$\mathrm{Cu}$ metal modified $\mathrm{HT} \mathrm{Mg}: \mathrm{Al}$ was prepared by memory effect [30], where typically, $1.0 \mathrm{~g}$ the as-prepared HT-As was treated with an aqueous $\mathrm{Cu}^{2+}$ nitrate or sulfate solution $(0.1 \mathrm{~mol} / \mathrm{L}, 100 \mathrm{~mL})$ with stirring at room temperature for 48 $\mathrm{h}$ to reconstruct into the layered hydrotalcite structure. The resulting products were filtered, washed several times with distilled water and dried at $100^{\circ} \mathrm{C}$ for 12 $\mathrm{h}$, while the HT-Cu catalyst was obtained.

Then $\mathrm{Cu}$-modified $\mathrm{Mg}$ - $\mathrm{Al}$ catalysts were prepared in oven at $500^{\circ} \mathrm{C}$ for $7 \mathrm{~h}$ under a flowing stream of pure $\mathrm{N}_{2}$.

\section{iii-Clacined Cu:Al (3:1) HT-5}

It was prepared also by coprecipitation methods as mentioned in literature, where mixing of magnesium nitrate $\mathrm{Cu} \mathrm{SO}_{4} \cdot 5 \mathrm{H}_{2} \mathrm{O} 0.028 \mathrm{~mol}$, and aluminium nitrate $\mathrm{Al}\left(\mathrm{NO}_{3}\right)_{3} 0.01 \mathrm{~mol}$, in a dist. $\mathrm{H}_{2} \mathrm{O}$, mix $(\mathrm{C})$, mixing of $0.7162 \mathrm{~mol}$ of $\mathrm{NaOH}$, and $0.2084 \mathrm{~mol}$ of $\mathrm{Na}_{2} \mathrm{CO}_{3}$, in a dist. $\mathrm{H}_{2} \mathrm{O}$, mix (D). Drop using a burette drops from Mix (C) and Mix (D) to a round bottle flask 1L containing $0.5 \mathrm{~L}$ distilled water under vigorous stirring and heating at $60^{\circ} \mathrm{C}$ and measure $\mathrm{pH}$ during precipitation to be $10-11$. Keep the temperature at $60^{\circ} \mathrm{C}$ overnight $(16 \mathrm{~h})$ in water bath. Filter using (Whatmann 1 filter paper) and washing the cake by hot distilled water till $\mathrm{pH}=7$ gives (HT-5). Dry the filtrate at $80^{\circ} \mathrm{C}$ in an oven for $16 \mathrm{~h}$. Heat $2 \mathrm{~g}$ of the above paste product in oven at $450^{\circ} \mathrm{C}$ for $6 \mathrm{~h}$ in $\mathrm{N}_{2}$ atmosphere, 
then dissolve in adequate amount of $\mathrm{NaOH}(0.1 \mathrm{M})$ to form a paste. Dry the Paste at $80^{\circ} \mathrm{C}$ in an oven for $16 \mathrm{~h}$ gives HT-5.

2) Synthesis of $\beta$-Nitroalcohol, via Henry Reaction

a) Microwave Irradiation Method

i- Without Catalyst

A mixture of an aldehyde series $(10 \mathrm{mmol})$ and nitroalkane series $(10 \mathrm{mmol})$ were added to a vesicle, and the mixture was mixed strongly with a glass-rod at room temperature. The mixture was added in a Teflon vial and irradiated under $350 \mathrm{~W}$ microwave till the reaction temperature raised to $120^{\circ} \mathrm{C}$ with fixed microwave pressure. The vial was exposed to microwaves for a required time to complete the reaction. Check the reaction and monitor it using TLC using (eluent; Diethyl ether: chloroform) every $1 \mathrm{~min}$. until the reaction reached the end. Then the product mixture was cooled and extracted using ethanol analytical grade. The process were repeated using different aldehyde and different to form compounds from a - o.

The product compounds were purified by crystallization using EtOH/DMF solvent mixture to afford the pure crude $\beta$-nitroalcoohls a - o in an excellent yield.

\section{ii- Using catalyst}

Catalysts $0.5 \mathrm{~g}$ from HT- 1 up to HT- 5 were used and added by repeated adequate sequence to a reaction mixture as mentioned above for the series a - o till the reaction completed as before.

Each time and each run the catalysts were removed by filtration and washing by hot ethanol after that the excess solvent was removed by vaporization to get the final solid product. The product compounds were purified by crystallization using EtOH/DMF solvent mixture to afford the pure crude $\beta$-nitroalcoohls a - o in an excellent yield.

\section{b) Conventional Method}

The reaction were carried on electrical heating hotplate with stirrer and the methods as mentioned above in microwave irradiated were applied without catalyst at $90^{\circ} \mathrm{C}$ and with the catalysts series at $60^{\circ} \mathrm{C}$ for the series of catalysts and series of the aldehydes and nitro alkanes. The reactants aldehydes, nitroalkanes and catalyst were added together in a round flask bottle, closed with rubber septum connected to a condenser, after the completion of the reaction, the mixture cooled room air temperature then separated and purified as above mentioned and also the catalyst was treated as the above method.

i- p-2-Nitroethenylchlorobenzene $\left(\mathrm{C}_{8} \mathrm{H}_{6} \mathrm{ClNO}_{2}\right)$ mp. $262^{\circ} \mathrm{C}$, IR (KBr) $v$ max $/ \mathrm{cm}^{-1}: 1515-1560\left(\mathrm{NO}_{2}\right),{ }^{1} \mathrm{H}$ NMR (DMSO): $\delta 5.1$ (d, $1 \mathrm{H},-\mathrm{C}=\mathrm{C}), 5.6(\mathrm{~d}, 1 \mathrm{H},-\mathrm{C}=\mathrm{C}) \delta 7.27-7.4(\mathrm{dd}, 4 \mathrm{H}, \mathrm{Ar}),{ }^{13} \mathrm{C} \mathrm{NMR}(\mathrm{CDCl} 3): \delta$ 77.8, 111.22, 127.4, 128.2, 131.8, 134.3, 134.7, MS (m/z): $183.01\left(\mathrm{M}^{+}\right)$, Anal. Calcd for $\mathrm{C}_{8} \mathrm{H}_{6} \mathrm{ClNO}_{2}$ (183.6), C-52.61; Cl-19.31; H-3.3; N-7.65\% Found: C-52.66; Cl-19.3; H-3.3; N-7.63; \%.

ii- 1 - $\left(p\right.$-Chlorophenyl)-2-nitro-1-propene $\left(\mathrm{C}_{9} \mathrm{H}_{8} \mathrm{ClNO}_{2}\right)$ 
mp. $386^{\circ} \mathrm{C}$, IR ( $\left.\mathrm{KBr}\right) v \max / \mathrm{cm}^{-1}: 1525-1570\left(\mathrm{NO}_{2}\right),{ }^{1} \mathrm{H}$ NMR (DMSO): $\delta 1.7$ $\left(\mathrm{d}, 3 \mathrm{H}, \mathrm{CH}_{3}\right), \delta 4.9(\mathrm{q}, 1 \mathrm{H},-\mathrm{C}=\mathrm{CH}), \delta 7.2-7.45(\mathrm{dd}, 4 \mathrm{H}, \mathrm{Ar}), 13 \mathrm{C}$ NMR (CDCl3): $\mathrm{H}, \mathrm{CH}), \delta 7.27-7.4$ (dd, $4 \mathrm{H}, \mathrm{ArH}$ 's), ${ }^{13} \mathrm{C} \mathrm{NMR}\left(\mathrm{CDCl}_{3}\right): \delta 25.5,39.5$, 77.82, 81.1 126.66, 130.8, 134.5, MS (m/z): $230.01\left(\mathrm{M}^{+}\right)$, Anal. Calcd for $\mathrm{C}_{10} \mathrm{H}_{12} \mathrm{ClNO}_{3}$ (229), C-52.30; Cl-15.44; H-5.27; N-6.10\% Found: C-52.2; Cl-15.44; $\mathrm{H}-4.01 ; \mathrm{N}-6.8$; \%.

iii- 1-(4-chlorophenyl)-2-methyl-2-nitropropan-1-ol $\left(\mathrm{C}_{10} \mathrm{H}_{12} \mathrm{ClNO}_{3}\right)$

mp. $465^{\circ} \mathrm{C}$, IR (KBr) $v \max / \mathrm{cm}^{-1}: 1530\left(\mathrm{NO}_{2}\right),{ }^{1} \mathrm{H}$ NMR (DMSO): $\delta 1.1(\mathrm{~s}, 3 \mathrm{H}$, $\left.\mathrm{CH}_{3}\right), \delta 5.1(\mathrm{~s}, \mathrm{H}, \mathrm{CH}), \delta 7.27-7.4$ (dd, $4 \mathrm{H}, \mathrm{ArH}$ 's), ${ }^{13} \mathrm{C} \mathrm{NMR}\left(\mathrm{CDCl}_{3}\right): \delta 25.5$, 39.5, 77.82, 81.1 126.66, 130.8, 134.5, MS (m/z): $230.01\left(\mathrm{M}^{+}\right)$, Anal. Calcd for $\mathrm{C}_{10} \mathrm{H}_{12} \mathrm{ClNO}_{3}$ (229), C-52.30; Cl-15.44; H-5.27; N-6.10\% Found: C-52.2; Cl-15.44; $\mathrm{H}-4.01 ; \mathrm{N}-6.8$; \%.

iv- 2-Nitroethenyl-3,5-dibromobenzene $\mathrm{C}_{8} \mathrm{H}_{5} \mathrm{Br}_{2} \mathrm{NO}_{2}$ mp. 491, ${ }^{\circ} \mathrm{C}$, IR (KBr) $v$ max $/ \mathrm{cm}^{-1}: 1480\left(\mathrm{NO}_{2}\right), 670$ (C-Br), ${ }^{1} \mathrm{H}$ NMR (DMSO): $\delta \delta 5.2(\mathrm{~d}, 1 \mathrm{H},-\mathrm{C}=\mathrm{CH}), 6.2(\mathrm{~d}, 1 \mathrm{H},-\mathrm{C}=\mathrm{CH}), 7.7-7.9\left(\mathrm{~m}, 3 \mathrm{H}, \mathrm{ArH}\right.$ 's), ${ }^{13} \mathrm{C}$ NMR $\left(\mathrm{CDCl}_{3}\right): \delta 77.8,112.33,123,128,131.1,135.4,139.5, \mathrm{MS}(\mathrm{m} / \mathrm{z}): 306.5\left(\mathrm{M}^{+}\right)$, Anal. Calcd for $\mathrm{C}_{8} \mathrm{H}_{5} \mathrm{Br}_{2} \mathrm{NO}_{2}$ (307), Br-52; C-31.5; H-1.7; N-4.58\% Found: Br-51.7; C-30.57; H-1.6; N-4.46\%.

v- 1-(3,5-Dibromophenyl)-2-nitro-1-propene $\left(\mathrm{C}_{9} \mathrm{H}_{7} \mathrm{Br}_{2} \mathrm{NO}_{2}\right)$ mp. $538^{\circ} \mathrm{C}$, IR ( $\left.\mathrm{KBr}\right) v \max / \mathrm{cm}^{-1}: 1545\left(\mathrm{NO}_{2}\right), 672(\mathrm{C}-\mathrm{Br}),{ }^{1} \mathrm{H}$ NMR (DMSO): $\delta 1.1\left(\mathrm{~d}, 3 \mathrm{H}, \mathrm{CH}_{3}\right) \delta 3.45\left(\mathrm{~m}, 2 \mathrm{H}, \mathrm{CH}_{2}\right), \delta 5.15(\mathrm{~d}, 1 \mathrm{H},-\mathrm{CH}), \delta 7.27-7.8(\mathrm{~m}, 3 \mathrm{H}$, ArH's), ${ }^{13} \mathrm{C} \mathrm{NMR}\left(\mathrm{CDCl}_{3}\right): \delta 18.9,44.5,77.8,84.75,126.66,129.8,131.77,134.7$, MS (m/z): $338.9\left(\mathrm{M}^{+}\right)$, Anal. Calcd for $\mathrm{C}_{9} \mathrm{H}_{9} \mathrm{Br}_{2} \mathrm{NO}_{3}$ (339), Br-47.2; C-31.85; H-2.65; N-6.85\% Found: Br-47.14; C-31.89; H-2.68; N-4.13; \%.

vi- 1-(3,5-dibromophenyl)-2-methyl-2-nitropropan-1-ol $\mathrm{C}_{10} \mathrm{H}_{11} \mathrm{Br}_{2} \mathrm{NO}_{3}$ mp. $440.3^{\circ} \mathrm{C}$, IR (KBr) $v \max / \mathrm{cm}^{-1}: 3550(\mathrm{OH}), 1523-1550\left(\mathrm{NO}_{2}\right), 670(\mathrm{C}-\mathrm{Br})$, ${ }^{1} \mathrm{H}$ NMR (DMSO): $\delta 3.15$ (d, 2H, CH${ }_{2}$ ), $\delta 7.27-7.4$ (dd, $4 \mathrm{H}, \mathrm{ArH}$ 's), $\delta 5.2(\mathrm{t}, 1 \mathrm{H}$, $-\mathrm{CH}),{ }^{13} \mathrm{C}$ NMR (CDCl3): $\delta 25.5,39.8,77.8,88.7,124.4,129.8,131.1,135.1$, MS $(\mathrm{m} / \mathrm{z})$ : $353.3\left(\mathrm{M}^{+}\right)$, Anal. Calcd for $\mathrm{C}_{10} \mathrm{H}_{11} \mathrm{Br}_{2} \mathrm{NO}_{3}$ (353), Br-45.27; C-34.02; H-3.14; N-3.97\% Found: Br-45.3, C-34.01; H-3.15; N-3.95; \%.

vii- 1-(3,5-Dibromophenyl)-2-nitro-1-propene $\left(\mathrm{C}_{9} \mathrm{H}_{7} \mathrm{Br}_{2} \mathrm{NO}_{2}\right)$

mp. $362^{\circ} \mathrm{C}$, IR (KBr) $v \max / \mathrm{cm}^{-1}: 3600(\mathrm{OH}), 1520-1580\left(2 \mathrm{NO}_{2}\right), 675(\mathrm{C}-\mathrm{Br})$, ${ }^{1} \mathrm{H}$ NMR (DMSO): ): $\delta$ 1.75(d, 3H, $\left.\mathrm{CH}_{3}\right), 4.95$ (m, H, C=CH), $\delta 7.7-7.9(\mathrm{~m}, 3 \mathrm{H}$, ArH's), ${ }^{13} \mathrm{C} \mathrm{NMR}\left(\mathrm{CDCl}_{3}\right): \delta 24.9,77.8,119.83,123,128,130,131.5,139.5$, MS $(\mathrm{m} / \mathrm{z}): 320.91\left(\mathrm{M}^{+}\right)$, Anal. Calcd for $\mathrm{C}_{9} \mathrm{H}_{7} \mathrm{Br}_{2} \mathrm{NO}_{2}$ (321), Br-50; C-33.5; H-2.30; $\mathrm{N}-4.4 \%$ Found: $\mathrm{Br}-49.79$; C-33.68; H-2.20; N-4.36\%.

viii- 4-bromo-2-(1-hydroxy-2-nitropropyl)-6-nitrophenol

mp. $609^{\circ} \mathrm{C}$, IR ( $\left.\mathrm{KBr}\right) v \max / \mathrm{cm}^{-1}: 3650(\mathrm{OH}), 1540\left(2 \mathrm{NO}_{2}\right), 675(\mathrm{C}-\mathrm{Br}),{ }^{1} \mathrm{H}$ NMR (DMSO): $\delta 1.75\left(\mathrm{~d}, 3 \mathrm{H}, \mathrm{CH}_{3}\right), 4.95(\mathrm{~m}, \mathrm{H}, \mathrm{C}=\mathrm{CH}), \delta 6.5-7.2(\mathrm{dd}, 2 \mathrm{H}$, ArH's), ${ }^{13} \mathrm{C}$ NMR $\left(\mathrm{CDCl}_{3}\right): \delta 18.5,44.37,77.82,84.1,110.86,112.4,117.4,118.3$, 144.3, 146.27, MS $(\mathrm{m} / \mathrm{z})$ : $319.5\left(\mathrm{M}^{+}\right)$, Anal. Calcd for $\mathrm{C}_{9} \mathrm{H}_{9} \mathrm{BrN}_{2} \mathrm{O}_{6}(321)$, Br-24.89; C-33.67; H-2.83; N-8.72 Found: Br-24.89; C-33.8; H-2.87; N-8.6\%.

ix- 4-bromo-2-(1-hydroxy-2-methyl-2-nitropropyl)-6-nitrophenol 
mp. $765^{\circ} \mathrm{C}$, IR (KBr) $v$ max $/ \mathrm{cm}^{-1}: 3500-3700(2 \mathrm{OH}), 1520$ - $1580\left(2 \mathrm{NO}_{2}\right), 690$ (C-Br), ${ }^{1} \mathrm{H}$ NMR (DMSO): $\delta 1.09,(\mathrm{~s}, 3 \mathrm{H}, \mathrm{CH} 3), \delta 5.2(\mathrm{~s}, 1 \mathrm{H},-\mathrm{CH}), \delta 6.5-7.2(\mathrm{~m}$, $2 \mathrm{H}, \mathrm{ArH}$ 's), ${ }^{13} \mathrm{C}$ NMR $\left(\mathrm{CDCl}_{3}\right): \delta 25.1,39.48,88.7,110.86,112.36,117.5,118.3$, 145.3, 147.9, MS $(\mathrm{m} / \mathrm{z}): 334.9\left(\mathrm{M}^{+}\right)$, Anal. Calcd for $\mathrm{C}_{10} \mathrm{H}_{11} \mathrm{BrN}_{2} \mathrm{O}_{6}$ (335), Br-23.84; C-35.9; H-3.3; N-8.4\% Found: Br-Br-23.84; C-35.75; H-3.35; N-8.36\%.

\section{$\mathrm{x}$ - 2-nitro-1-(2-nitrophenyl) ethanol}

mp. $428.8^{\circ} \mathrm{C}$, IR (KBr) $v \max / \mathrm{cm}^{-1}: 1510-1555\left(2 \mathrm{NO}_{2}\right),{ }^{1} \mathrm{H}$ NMR (DMSO): $\delta$ $3.15\left(\mathrm{~d}, 2 \mathrm{H}, \mathrm{CH}_{2}\right), \delta 5.15(\mathrm{t}, 1 \mathrm{H},-\mathrm{CH}), \delta 6.66-7.3$ (m, 4H, ArH's), 13C NMR (CDCl3): $\delta 49.5,77.8,81.1,112.87,116.8,126.66,129.4,150.97, \mathrm{MS}(\mathrm{m} / \mathrm{z}): 212$ $\left(\mathrm{M}^{+}\right)$, Anal. Calcd for $\mathrm{C}_{8} \mathrm{H}_{8} \mathrm{~N}_{2} \mathrm{O}_{5}$ (212), C-45.29; H-3.80; N-13.20\% Found: C-45.29; H-3.80; N-13.20; \%.

\section{xi- 2-nitro-1-(2-nitrophenyl) propan-1-ol}

mp. $552^{\circ} \mathrm{C}$, IR (KBr) $v \max / \mathrm{cm}^{-1}: 1515-1560\left(2 \mathrm{NO}_{2}\right),{ }^{1} \mathrm{H}$ NMR (DMSO): $\delta$ 1.04, (d, 3H, CH3), $\delta 3.45$ (m, H, CH), $\delta 5.15(\mathrm{~d}, \mathrm{H}, \mathrm{CH}), \delta 6.7-7.3(\mathrm{~m}, 4 \mathrm{H}$, ArH's), ${ }^{13} \mathrm{C} \mathrm{NMR}\left(\mathrm{CDCl}_{3}\right): \delta 18.1,44.73,77.8,84.74,112.87,116.75,129.3,150.9$, MS (m/z): $226\left(\mathrm{M}^{+}\right)$, Anal. Calcd for $\mathrm{C}_{9} \mathrm{H}_{10} \mathrm{~N}_{2} \mathrm{O}_{5}$ (226.2), C-47.79; H-4.46; $\mathrm{N}-12.39 \%$ Found: C-47.79; H-4.46; N-12.39\%.

\section{xii- 2-methyl-2-nitro-1-(2-nitrophenyl)propan-1-ol}

mp. $453.3^{\circ} \mathrm{C}$, IR (KBr) $v \max / \mathrm{cm}^{-1}: 3650(\mathrm{OH}), 1520-1570\left(2 \mathrm{NO}_{2}\right),{ }^{1} \mathrm{H}$ NMR (DMSO): $\delta 1.04$ (s, 3H, $\mathrm{CH}_{3}$ ), $\delta 5.15$ (s, H, CH), $\delta 6.7-7.2\left(\mathrm{~m}, 4 \mathrm{H}, \mathrm{ArH}{ }^{\prime} \mathrm{s}\right),{ }^{13} \mathrm{C}$ NMR $\left(\mathrm{CDCl}_{3}\right): \delta 25.12,39.9,77.82,88.65,112.86,116.75,129.36,150.99$, MS $(\mathrm{m} / \mathrm{z}): 240.12\left(\mathrm{M}^{+}\right)$, Anal. Calcd for $\mathrm{C}_{10} \mathrm{H}_{12} \mathrm{~N}_{2} \mathrm{O}_{5}$ (240), C-50.00; H-5.04; $\mathrm{N}-11.66 \%$ Found: C- 49.90; H-5; N-11.66\%.

\section{xiii- 1-(4-methoxyphenyl)-2-nitroethanol}

mp. $443.87^{\circ} \mathrm{C}$, IR (KBr) $v \max / \mathrm{cm}^{-1}: 1545\left(\mathrm{NO}_{2}\right), 1150$ (C-O), ${ }^{1} \mathrm{H}$ NMR (DMSO): $\delta 3.15$ (s, H, $\mathrm{CH}_{3}$ ), $\delta 5.2(\mathrm{t}, 1 \mathrm{H},-\mathrm{CH}), \delta 6.57-7.2$ (m, 4H, ArH's), ${ }^{13} \mathrm{C}$ $\operatorname{NMR}\left(\mathrm{CDCl}_{3}\right): \delta 49.5,65.5,77.8,114.2,120.86,129.56,159.96, \mathrm{MS}(\mathrm{m} / \mathrm{z}): 197.2$ $\left(\mathrm{M}^{+}\right)$, Anal. Calcd for $\mathrm{C}_{9} \mathrm{H}_{11} \mathrm{NO}_{4}$ (197), C-54.9; H-5.62; N-7.10\% Found: C-54.8; H-5.66; N-7\%.

\section{xiv- 1-(4-methoxyphenyl)-2-nitropropan-1-ol}

mp. $440^{\circ} \mathrm{C}$, IR (KBr) $v$ max $/ \mathrm{cm}^{-1}: 1565\left(\mathrm{NO}_{2}\right), 1210$ (C-O), ${ }^{1} \mathrm{H}$ NMR (DMSO): $\delta 1.04\left(\mathrm{~d}, 3 \mathrm{H}, \mathrm{CH}_{3}\right), \delta 3.14\left(\mathrm{~s}, 3 \mathrm{H}, \mathrm{CH}_{3}\right), \delta 3.5(\mathrm{~m}, 1 \mathrm{H},-\mathrm{CH}), \delta 5.3(\mathrm{~d}, \mathrm{H}, \mathrm{CH}), \delta$ 7.27 - $7.4\left(\mathrm{~m}, 4 \mathrm{H}, \mathrm{ArH}\right.$ 's), ${ }^{13} \mathrm{C} \mathrm{NMR}\left(\mathrm{CDCl}_{3}\right): \delta 18.02,44.95,65.01,77.8,84.7$, 114.16, 120.86, 129.6, 159.99, MS (m/z): $211.2\left(\mathrm{M}^{+}\right)$, Anal. Calcd for $\mathrm{C}_{10} \mathrm{H}_{13} \mathrm{NO}_{3}$ (211), C-56.86; H-6.20; N-6.63\% Found: C-56.86; H-6.20; N-6.63\%.

xv- 1-(4-methoxyphenyl)-2-methyl-2-nitropropan-1-ol

mp. $468.8^{\circ} \mathrm{C}$, IR (KBr) $v \max / \mathrm{cm}^{-1}: 3650(\mathrm{OH}), 1535\left(\mathrm{NO}_{2}\right), 1050(\mathrm{C}-\mathrm{O}),{ }^{1} \mathrm{H}$ NMR (DMSO), $\delta 1.04\left(\mathrm{~s}, 3 \mathrm{H}, \mathrm{CH}_{3}\right), \delta 3.14\left(\mathrm{~s}, 3 \mathrm{H}, \mathrm{CH}_{3}\right), \delta 5.2(\mathrm{~s}, \mathrm{H}, \mathrm{CH}), \delta 6.9-$ 7.3 (m, 4H, ArH's), ${ }^{13} \mathrm{C}$ NMR $\left(\mathrm{CDCl}_{3}\right): \delta 18.02,44.95,65.01,77.8,84.7,114.16$, 120.86, 129.6, 159.99, MS (m/z): $225.3\left(\mathrm{M}^{+}\right)$, Anal. Calcd for $\mathrm{C}_{11} \mathrm{H}_{15} \mathrm{NO}_{3}(225)$, C-58.66; H-6.71; N-6.22\% Found: C-58.66; H-6.71; N-6.22; \%.

\section{Conclusion}

In brief, we reported Henry reaction between benzaldehyde and nitromethane 
over solid base catalysts. Cu:Mg:Al-HT catalyst gave a precious advantage over all solid base catalysts under investigation especially calcied Cu:Al 3:1 (HT-5). Microwave irradiation technique introduced us high yields of $\beta$ - alcohol derivatives using the prepared series of HT solid catalyst in very short time. Strong Basic characterization of catalyst was responsible for the power of catalytic activity. HT series kept their physical properties (texture and structure) even after many catalytic runs, which facilitated gaining of high yields beta nitro alcohols. These synthesized derivatives are of great importance in industry and medical uses.

\section{Acknowledgements}

The authors are very grateful to Taif University, Taif, KSA, because this work was financial supported by Taif University, Taif, KSA, under project number 1/437/4938. The authors express their great thanks to Prof. Dr. Mohamed Mokhtar, Chemistry Department, Faculty of Science, King Abdualziz University, Jeddah, KSA, for help and advices.

The authors presented the abstract as poster at Green and sustainable chemistry conference 13-15 May 2017, Berlin.

\section{Conflict of Interest}

The authors declare that, there is no conflict of interest.

\section{References}

[1] Olah, G.A., Krishnamurti, R. and Prakash, G.K.S. (1991) Comprehensive Organic Synthesis. Pergamom Press, Oxford, 293-339. https://doi.org/10.1016/B978-0-08-052349-1.00065-2

[2] Rosini, G. (1991) Comprehensive Organic Synthesis. Pergamon Press, Oxford, 321.

[3] Ballini, R., Bosica, G. and Forconi, P. (1996) Nitroaldol (Henry) Reaction Catalyzed by Amberlyst A-21 as a Far Superior Heterogeneous Catalyst. Tetrahedron, 52, 1677-1684. https://doi.org/10.1016/0040-4020(95)00996-5

[4] Contantino, U., Curini, M., Marmottini, F., Rosati, O. and Pisani, E. (1994) Potassium Exchanged Layered Zirconium Phosphate as Base Catalyst in the Synthesis of 2-Nitroalkanols. Chemistry Letters, 23, 2215. https://doi.org/10.1246/cl.1994.2215

[5] Sheldon, R.A. (1997) Catalysis: The Key to Waste Minimization. Journal of Chemical Technology \& Biotechnology, 68, 381-388.

[6] Choudary, B.M., Lakshmi Kantam, M., Venkat Reddy, C., Koteswara Rao, K. and Figueras, F. (1999) Henry Reactions Catalysed by Modified Mg-Al Hydrotalcite: An Efficient Reusable Solid Base for Selective Synthesis of $\beta$-Nitroalkanols. Green Chemistry, 1, 187-189. https://doi.org/10.1039/a904075g

[7] Choudary, B.M., Kantam, M.L. and Kavita, B. (2001) Synthesis of 2-Nitroalkanols by $\mathrm{Mg}_{3} \mathrm{Al}_{2} \mathrm{O}-t-\mathrm{Bu}$ Hydrotalcite. Journal of Molecular Catalysis A: Chemical, 169, 193-197. https://doi.org/10.1016/S1381-1169(00)00558-6

[8] Seebach, D., Beck, A.K., Mukhopdyay, T. and Thomas, E.H. (1982) Diastereoselective Synthesis of Nitroaldol Derivatives. Helvetica Chimica Acta, 65, 1101-1133.

[9] Bulbule, V.J., Deshpande, V.H., Velu, S., Sudalai, A., Sivasankar, S. and Sathe, V.T. (1999) Heterogeneous Henry Reaction of Aldehydes: Diastereoselective Synthesis of 
Nitroalcohol Derivatives over Mg-Al Hydrotalcites. Tetrahedron, 55, 9325-9332. https://doi.org/10.1016/S0040-4020(99)00494-9

[10] de Vries, A.H.M., de Vries, J.G., van Assema, F.B.J., de Lange, B., Mink, D. and Hyett, D.J. (2011) Asymmetric Synthesis of (S)-2-Indolinecarboxylic Acid by Combining Biocatalysis and Homogeneous Catalysis. ChemCatChem, 3, 289-292.

[11] Rosini, G., Ballini, R. and Sorrenti, P. (1983) Synthesis of 2-Nitroalkanols on Alumina Surfaces without Solvent: A Simple, Mild and Convenient Method. Synthesis, 1983, 1014-1016.

[12] Melot, J.M., Texier-Boullet, F. and Foucaud, A. (1986) Preparation and Oxidation of $\alpha$-Nitro Alcohols with Supported Reagents. Tetrahedron Letters, 27, 493-496. https://doi.org/10.1016/S0040-4039(00)85513-6

[13] Ballini, R. and Bosica, G. (1997) Nitroaldol Reaction in Aqueous Media: An Important Improvement of the Henry Reaction. The Journal of Organic Chemistry, 62, 425-427. https://doi.org/10.1021/jo961201h

[14] Kloetstra, K.R. and Van Bekkum, H. (1995) Base and Acid Catalysis by the Alkali-Containing MCM-41 Mesoporous Molecular Sieve. Journal of the Chemical Society, Chemical Communications, No. 10, 1005-1006.

https://doi.org/10.1039/c39950001005

[15] Mokhtar, M., Saleh, T.S., Ahmed, N.S., Al-Thabaiti, S.A. and Al-Shareef, R.A. (2011) An Eco-Friendly $N$-Sulfonylation of Amines Using Stable and Reusable Zn-Al-Hydrotalcite Solid Base Catalyst under Ultrasound Irradiation. Ultrasonics Sonochemistry, 18, 172-176. https://doi.org/10.1016/j.ultsonch.2010.05.001

[16] Mokhtar, M., Saleh, T.S. and Basahel, S.N. (2012) Mg-Al Hydrotalcites as Efficient Catalysts for Aza-Michael Addition Reaction: A Green Protocol. Journal of Molecular Catalysis A: Chemical, 353-354, 122-131.

[17] Saleh, T.S., Narasimharao, K., Ahmed, N.S., Basahel, S.N., Al-Thabaiti, S.A. and Mokhtar, M. (2013) Mg-Al Hydrotalcite as an Efficient Catalyst for Microwave Assisted Regioselective 1,3-Dipolar Cycloaddition of Nitrilimines with the Enaminone Derivatives: A Green Protocol. Journal of Molecular Catalysis A: Chemical, 367, $12-22$.

[18] Narasimharao, K., Al-Sabban, E., Saleh, T. and Gallastegui, A.G., Sanfiz, A.C., Basahel, S., Al-Thabaiti, S., Alyoubi, A., Obaid, A. and Mokhtar, M. (2013) Microwave Assisted Efficient Protocol for the Classic Ullman Homocoupling Reaction Using Cu-MG-Al Hydrotalcite Catalysts. Journal of Molecular Catalysis A: Chemical, 379, 152-162. https://doi.org/10.1016/j.molcata.2013.08.013

[19] Basahel, S.N., Al-Thabaiti, S.A., Narasimharao, K., Ahmed, N.S. and Mokhtar, M. (2014) ChemInform Abstract: Nanostructured Mg-Al Hydrotalcite as Catalyst for Fine Chemical Synthesis. Journal of Nanoscience and Nanotechnology, 14, 1931-1946.

[20] Celaya-Sanfiz, A., Morales-Vega, N., De Marco, M., Iruretagoyena, D., Mokhtar, M., Bawaked, S.M., Basahel, S.N., Al-Thabaiti, S.A., Alyoubi, A.O. and Shaffer, M.S.P. (2015) Self-Condensation of Acetone over Mg-Al Layered Double Hydroxide Supported on Multi-Walled Carbon Nanotube Catalysts. Journal of Molecular Catalysis A: Chemical, 398, 50-57. https://doi.org/10.1016/j.molcata.2014.11.002

[21] Phukan, M., Borah, K.J. and Borah, R. (2009) Henry Reaction in Environmentally Benign Methods Using Imidazole as Catalyst. Green Chemistry Letters and Reviews, 2, 249-253. https://doi.org/10.1080/17518250903410074

[22] Li, T.F., Miras, H.N. and Song, Y.-F. (2017) Polyoxometalate (POM)-Layered 
Double Hydroxides (LDH) Composite Materials: Design and Catalytic Applications. Catalysts, 7, 260. https://doi.org/10.3390/catal7090260

[23] Nakhate, A.V., Rasal, K.B., Deshmukh, G.P., Gupta, S.S.R. and Mannepalli, L.K. (2017) Synthesis of Quinoxaline Derivatives from Terminal Alkynes and O-Phenylenediamines by Using Copper Alumina Catalyst. Journal of Chemical Sciences, 129, 1761-1769. https://doi.org/10.1007/s12039-017-1393-0

[24] Wang, D.F., Zhang, X.L., Liu, C.L., Cheng, T.T., Wei, W. and Sun, Y.H. (2015) Transition Metal-Modified Mesoporous Mg-Al Mixed Oxides: Stable Base Catalysts for the Synthesis of Diethyl Carbonate from Ethyl Carbamate and Ethanol. Applied Catalysis A: General, 505, 478-486.

[25] Jitianu, M., Gunnes, D.C., Aboghye, D.E., Zaharescu, M. and Jitianu, A. (2013) Nanosized Ni-Al Layered Double Hydroxides-Structural Characterization. Materials Research Bulletin, 48, 1864-1873. https://doi.org/10.1016/j.materresbull.2013.01.030

[26] Das, D.P., Das, J. and Parida, K. (2003) Physicochemical Characterization and Adsorption Behavior of Calcined Zn/Al Hydrotalcite-Like Compound (HTlc) towards Removal of Fluoride from Aqueous Solution. Journal of Colloid and Interface Science, 261, 213-220. https://doi.org/10.1016/S0021-9797(03)00082-1

[27] Pil, K., Younghun, K., Heesoo, K., In, K.S. and Jongheop, Y. (2004) Synthesis and Characterization of Mesoporous Alumina with Nickel Incorporated for Use in the Partial Oxidation of Methane into Synthesis Gas. Applied Catalysis A: General, 272, 157-166. https://doi.org/10.1016/j.apcata.2004.05.055

[28] Renuka, N.K., Shijina, A.V., Praveen, A.K. and Aniz, C.U. (2014) Redox Properties and Catalytic Activity of $\mathrm{CuO} / \gamma-\mathrm{Al}_{2} \mathrm{O}_{3}$ Meso Phase. Journal of Colloid and Interface Science, 434, 195-200. https://doi.org/10.1016/j.jcis.2014.08.005

[29] Sun, Z.X., Zheng, T.T., Bo, Q.B., Du, M. and Forsling, W. (2015) Effects of Calcination Temperature on the Pore Size and Wall Crystalline Structure of Mesoporous Alumina. Journal of Colloid and Interface Science, 319, 247-251,

[30] Kuma, P.A., Reddy, M.P., Ju, L.K., Hyun-Sook, B. and Phil, H.H. (2008) Low Temperature Propylene SCR of NO by Copper Alumina Catalyst. Journal of Molecular Catalysis A: Chemical, 291, 66-74. https://doi.org/10.1016/j.molcata.2008.05.006 